\title{
Supply Chain Management for Sustainable RMG Growth in Bangladesh
}

\author{
Md. Uzzal Hossain ${ }^{1}$, Ishita Roy ${ }^{2}$ \\ ${ }^{1}$ Lecturer, Department of Management Studies, Bangabandhu Sheikh Mujibur Rahman Science \& Technology University, Gopalganj-8100 \\ ${ }^{2}$ Assistant Professor, Department of Management Studies, Bangabandhu Sheikh Mujibur Rahman Science \& Technology University, \\ Gopalganj-8100
}

\begin{abstract}
The aim of this paper is to identify the impact of Supply Chain Management (SCM) for sustainable growth in Readymade Garments (RMG) sector of Bangladesh. The export-oriented RMG sector has some distinctive features, which differentiate it from other businesses. Wage, supply chain, timeframe, and compliances are among the most important features of this business. Whatever the wage level or lead time is without proper supply chain management no business is viable. RMG manufacturing is one of the suitable examples of the supply chain management. Data for this study is mainly collected from secondary sources. The study revels that the decision makers and planners of RMG should align their supply chain strategies, work together with all the supply chain partners, share infomration among the stages of supply chain, have a standard SCM procedure, comply the code of conduct, adapt changing technologies, minimize corruption and bureaucratic tangles in customs, cut lead time etc to sustain its growth. The most important limitation of this paper was to use data from secondary sources that might limit the generalizability of the results.
\end{abstract}

Keywords: Supply Chain Management, Ready-Made Garment, Competitive Advantage, SCM Procedure, Export Oriented.

\section{Introduction}

RMG is the leading sector in Bangladesh in terms of foreign currency earnings. Bangladesh is the second largest garments exporter next to china. It contributes $80 \%$ of total export earnings. In Bangladesh there are 4 million people, working in around 6000 garments factories and approximately $80 \%$ people of them are female. In FY (fiscal year) 2012-2013 Bangladesh reached the export value 21b (billion) USD (21515.73m (million) USD). In FY 20132014 the strategic target was 24147.31m USD by export promotion bureau of Bangladesh, but in July_13 -April'14 it reaches $19970.02 \mathrm{~m}$ USD that is $2.72 \%$ more than the strategic target (19441m USD) during this time. RMG sector has set a target to earn 30b USD by 2015 and 50b USD by 2021. Low labor cost, efficient worker, different organizational support and government support are the main strengths of this sector. Bangladesh market share is 5\% of total global RMG market of 450b USD. In FY 2012- 2013 Bangladesh exported $1972.89 \mathrm{~m}$ USD of shirts, $5185.48 \mathrm{~m}$ USD of trousers, 2634.28m USD of jackets and $5143.22 \mathrm{~m}$ USD of t-shirts. The major importers are European Union, USA and Canada. Knit garments are exported to 148 countries and woven garments are exported to 132 countries. The major buyers are Wal-Mart, Target, Marks and Spencer, Tesco, Levi's, Zara, JC Penny, GAP, C \& A, UNIQLO etc.

On the contrary, Supply Chain Management is such kind of Management dealing with customer contentment concerning Manufacturing and Service which are the key values for the Bangladesh Garment Industry obviously. It Constance all of the customer requirement and essential it's all about customer (buyer in term of garment industry) satisfaction. Supply Chain Management (SCM) is such kind of Management for a network of intra and interconnected businesses (Supplier to Manufacturer to Buyer) engaged in the provision of goods and service packs (Lead Time or up to Shipment) needed by the bottom end customers in a supply chain. Supply chain management extents all attempts and procurements of raw materials like trims and accessories, work-in-process inventory, and completed goods from source of origin to source of consumption inside the garment commerce. So according to the nearby scenario Supply Chain Management is in actuality offering a New Paradigm for Bangladesh Garment Industry undoubtedly. Supply chain management systems help in reducing inventories, operational costs, compress order cycle time, enhance asset productivity as well as increase the companies' responsiveness to the market. Besides from these benefits, the apparel industry is able to achieve quick response through efficient supply chain management practices. Quick response is a concept pertaining to the collaboration and sharing or information among manufacturers, suppliers and distributors, allowing them to respond more rapidly to the needs of the customers.

Since entering into the 21st Century, Bangladeshi RMG and apparel industry begun to face increasingly serious problems with offering high-quality, low-cost products within a short lead time; and to meet health, social, and environmental compliances in the face of increasingly stiff completion. Under this domestic and foreign competitive environment, the future survival and development of Bangladeshi RMG industry faces large challenge. Simple management mode of made of import to export" or the production and management mode of -ertical integration" have made the Bangladeshi RMG industry lack in activity, innovational ability and insufficient international competition. Under this background, the idea of - hrizontal integration" begins to rise, and as the representative of this idea, the supply chain management (SCM) increasingly prevails. Because of enormous economic importance in the economy of Bangladesh, RMG industry growth is to be sustained by improving SCM. 


\section{International Journal of Science and Research (IJSR) \\ ISSN (Online): 2319-7064}

Index Copernicus Value (2013): 6.14 | Impact Factor (2015): 6.391

\section{Literature Review}

The RMG industry is highly dependent on imported raw materials. About $90 \%$ of woven fabrics and $60 \%$ of knit fabrics are imported to make garments for export (Rashid, 2006; Rahman \& Anwar, 2006). Besides rudimentary application of information and communication technology (ICT) and inefficient port management limits its ability to respond quickly to market change, which is very essential in the fashion market (Abdullah, 2008). Therefore, this industry takes maximum lead time to process an order (Hege, 2004; Nuruzzaman, 2008; Kabir, 2007; Siddiqi, 2007). In Bangladesh, the lead time for apparel export varies between 90-120 days, whereas the time for Sri Lanka is about 19-45 days, China 40-50 days and for India 50-70 days for similar products (Rahman \& Anwar, 2006; Kabir, 2007). Lam and Postle (2006) discussed the strengths and problems faced by the Bangladeshi textile apparel supply chains. They argued that Bangladeshi apparel industry is generally not aware of the concept of SCM and industrial benchmark for both manufacturing and retailing industries in Bangladesh. Islam (2013) analyzed that apparel supply chain matters such as new orders, raw materials supply, production processes and logistics related to finished goods delivery by using efficient supply chain process and also mentioned that Bangladesh garment industry improvement is desired in reducing the supply time required to produce and fulfill the orders placed by foreign companies. His findings show that using modern, fast and effective machinery can reduce time taken to deliver the order. Working as supply chain incharge of Regency Garments Ltd, Gupta (2014) identified that the tremendous pressures of globalization and demanding customers require the RMG businesses to improve their quality, responsiveness and customer satisfaction, while making conscientious efforts to cut costs. So, the apparel makers need to focus on appropriate supply chain configuration to hold superior serviceability. Saiful and Noorul (2013) analyzed the approach is to compile the supply chain management or the Bangladesh garment industry seriously. Since the end consumers of the apparel fashion market are becoming increasingly time-sensitive, a decrease in lead time, besides quality and cost criteria, is needed to win more orders from buyers. Further, increased lead time and cost due to disruptions in procurement and shipment of goods (Nuruzzaman, 2009) lack of linkages and co-ordination among related industries in the value chain and dependence on imported inputs and limited variety finished products (Quashem 2002; Ahmed 2011), fall of order because of global economic downturn (Chowdhury 2012) are issues of high concern for RMG supply chain of Bangladesh.

\section{Objectives of the Study}

The objectives of the study are

3.1. To highlight about the supply chain of RMG industry.

3.2. To find out the role of supply chain in RMG industry of Bangladesh.

3.3. To ascertain the problems toward sustainable RMG growth from supply chain point of view.

\section{Methodology of the Study}

The study is mainly based on secondary data and merely on primary data. The secondary data have been collected from different books, journals, BGMEA and BKMEA reports, newspapers and publications on Bangladesh. Published and unpublished materials and papers available in the internet have also been reviewed for the purpose. On the other hand, interviews of professionals and merchandisers of the garments factory were the primary data source.

\section{Findings of the Study}

The findings of the study have been discussed under the following sub-heads:

\subsection{Bangladesh and its Garment Industry}

The readymade garment (RMG) industry acts as the backbone of Bangladesh economy and as a catalyst for the development of the country. Bangladeshi people take pride in the sector that has been fetching billions of dollars as export earnings and creating jobs for millions of people in the country. The elimination of quota system by developed countries importing garments and rising labor costs in that decade impeded the growth of this industry in East Asian nations and created new opportunities for the sector of Bangladesh (Rashid, 2006). Since the nineties the sector has played the biggest role in the ever-growing export sector of Bangladesh (Bajlul \& Naznin, 2006). In 1982-83, the RMG sector had a 1.1\% stake in the total export. In 2012-13, this grew to $79.63 \%$. It takes up $10 \%$ of the GDP (Mahmud, 2012), 14-15\% when put together with complementary industries. In 2012-13, this sector made an export income of 21.1 billion US dollars.

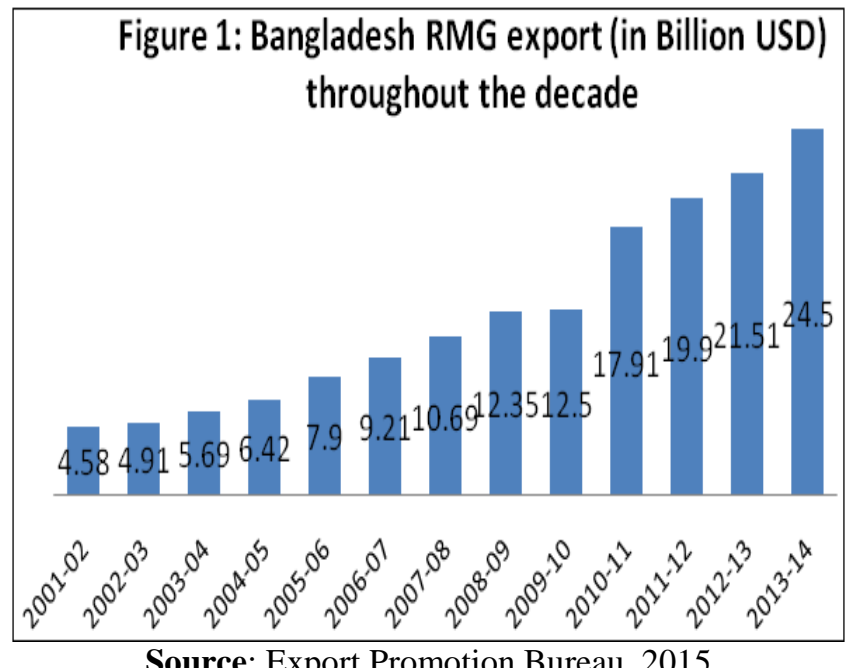

The RMG sector is the largest employer in the country and is considered the backbone of the country. In 1980, there were 50 garment factories in the country and they employed a few thousand (Kabir \& Mahmud, 2004). In 2012, there were 5400 factories in the country and employed about 4 million workers of whom $85 \%$ were women (Mahmud, 2012). For this reason, this sector is called the single largest employer of women in the country. This employment of rural low-income women has given them economic freedom 


\section{International Journal of Science and Research (IJSR) \\ ISSN (Online): 2319-7064 \\ Index Copernicus Value (2013): 6.14 | Impact Factor (2015): 6.391}

and increased their participation in the economic development of Bangladesh (Foujia, 2006).

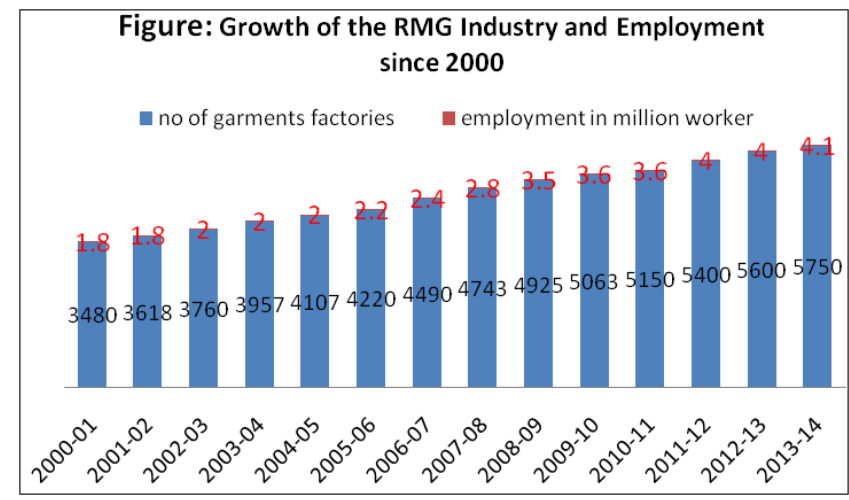

Source: Bangladesh Garment Manufacturers and Exporters Association, 2015

\subsection{SCM at RMG industry}

The supply chain process for manufacturing and service industries started with suppliers, manufacturers, distributors, retailers, customers and suppliers, service providers, customers and end with consumers respectively. The customers are the most vital focal point of the supply chain, since the primary purpose of the existence of any supply chain is to directly or indirectly satisfy customer needs. The basic supply chain of readymade garment industry in Bangladesh involves supplier, manufacturer, ultimate buyer and service provider. The basic diagram of supply chain in garment industry can be shown as follows:

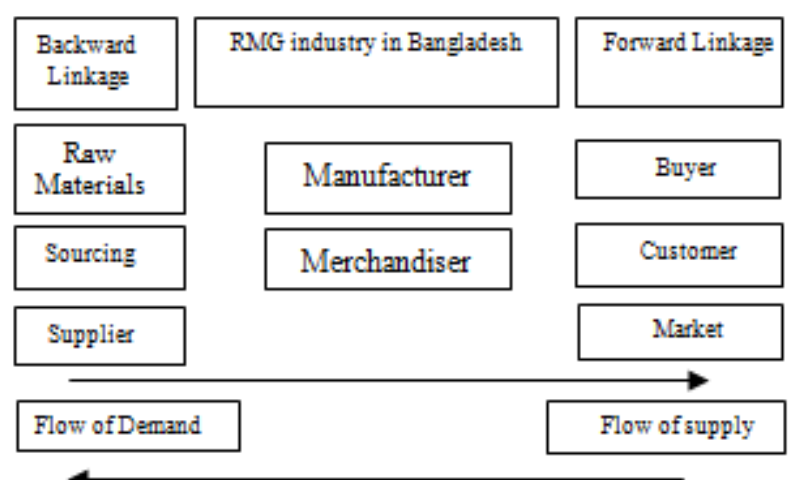

The basic Diagram of Supply Chain in Garment Industry (Tanvir \& Muqaddim, 2013)

In Bangladesh textile industry, there are two main groups of customers: domestic and export. With some assistance from logistics and distribution centers, the Bangladeshi textile products can be easily delivered to end-consumers as shown as follows:

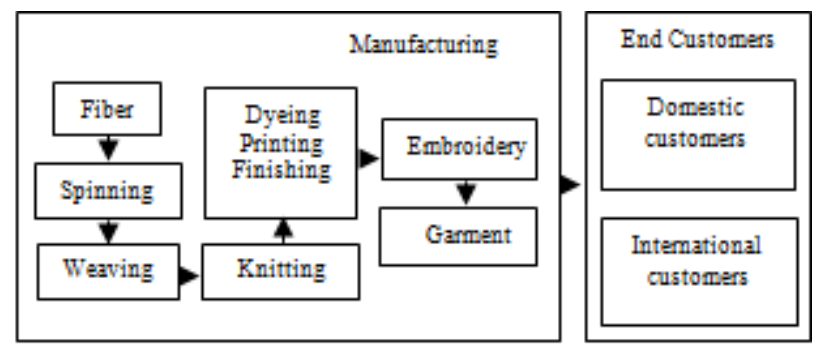

In reality, however, there are some other key players in the supply chain of Bangladeshi garments industry that have a major influence in the trading process. In case of the garment industry of Bangladesh, the actual exporting process usually involved with more members in the chain that can be depicted as follows:

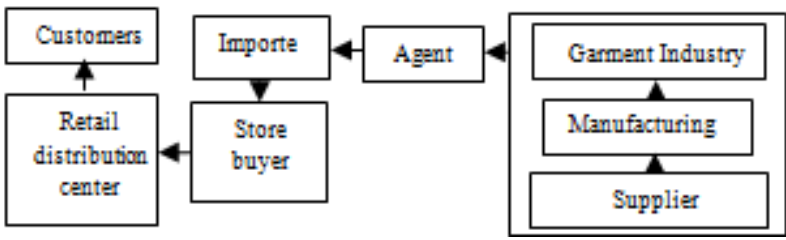

In RMG business, there is a very strong correlation between the business value chain and the supply chain. The supply chain is mostly controlled by the buyers who control the business. The supply chain of RMG sector consists of a number of discrete activities. The supply chain beginning with sourcing of raw material, design and production through to customer, is being organized as an integrated production system. The Supply Chain Activities at RMG industry of Bangladesh can be shown as follows

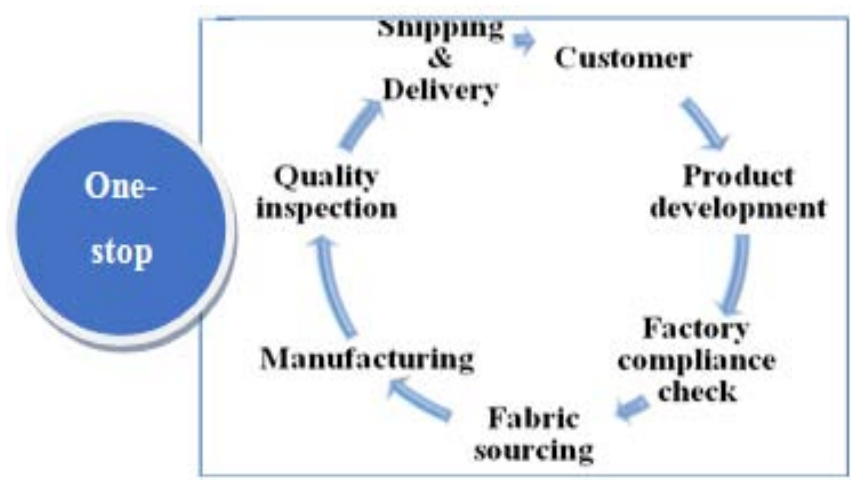

Figure: One stop servcies in the supply chain Source: The financial Express, 2014

\subsection{Importance of supply chain in the growth of RMG industry}

In today's highly competitive global marketplace customers are placing greater value on excellence and delivery time. Manufacturers similarly have begun to situate more value on quality and delivery time and companies need to try to swell a competitive perimeter and improve profitability through cutting cost, increasing quality and improving delivery by the assist of supply chain management. In the supply chain system, it can be materials, fund, information or it can even be supply of business (volume of business). One small material missing or delayed just puts the whole order at stake. Schedule failure for one single order delivery jeopardizes the whole production plan. Unplanned and earlier importation of materials increases the inventory level. Supply of materials, when delayed in-house, creates a line gap. Both the situations have a negative impact on finance. On the other hand, if the finished goods are not shipped on time due to not getting the approval, the factory has to pay the bills of back-to-back (BTB) L/Cs (letters of credit) against its bank loan at a high interest. So the factory always tries to avoid delayed shipment, even by covering that delay with overtime work, which leads to double production cost. 


\section{International Journal of Science and Research (IJSR) \\ ISSN (Online): 2319-7064 \\ Index Copernicus Value (2013): 6.14 | Impact Factor (2015): 6.391}

When this overtime work does not help, then they take the recourse to un-authorized sub-contracts. Excessive overtime work and un-authorized subcontracts both amount to violation of compliance, another inevitable feature of the sector.

In RMG business, manufacturers, suppliers, and buyers all stages of supply chain in the RMG sector are decentralized. Different stages of supply chain have conflicting goals and objectives. Carefully using the available information and integration of supply chain can reduce the cost of conflicting goals and objectives. Delivering the finished products on time from suppliers to customer would be possible through the proper application of supply chain management. Supply chain management systems help in reducing inventories, operational costs, compress order cycle time, enhance asset productivity as well as increase the companies" responsiveness to the market. Besides from these benefits, the apparel industry is able to achieve quick response through efficient supply chain management practices. Quick response is a concept pertaining to the collaboration and sharing or information among manufacturers, suppliers and distributors, allowing them to respond more rapidly to the needs of the customers.

If SCM or procedures is ended appropriately, it can assist the Bangladeshi garment industry to diminish their catalogs which will direct to cutting of operational costs, lessen order cycle time, enhance plus efficiency as well as augment the companies" receptiveness to the market. Improved or superior SCM also leads to quick response which is a concept pertaining to the collaboration and sharing or information among manufacturers, suppliers and distributors, permitting them to act in response more swiftly to the requirements of the clienteles. The garment's supply chain is diverse: a. raw material, b. divisions, c. ginning facilities, d. spinning and extrusion processes, e. processing sector, f. weaving and knitting factories and g. garment (and other stitched and non-stitched) manufacturing that supply an extensive distribution channel. This SCM process is possibly one of the most diverse in terms of the raw materials utilized, technologies installed and products formed. The demarcation of product strains into functional and innovative products assists the supply chain company to employ dissimilar supply chain strategies for different products, namely responsive supply chain strategy for pioneering products and efficiency supply chain strategy for purposeful products. Garment SCM is the beneficial ones for generating the order to the shipment (start to end) appropriately as per factory and the buyer's obligation. Apparel buyers around the sphere insist product as they want it, when they want it and the best possible price so that supply chain can do a lot to this concern in reality.

\subsection{Problems toward sustainable RMG growth:}

The RMG sector is now passing through many difficulties it never faced before. A devastating fire at the Tazreen Fashions and the Rana Plaza collapse have raised the question about its capability in terms of compliance, fire safety and building integrity. Only minimum wage competitiveness does not guarantee any international business of this kind. Hundreds of factories are closed, thousands of workers have lost their jobs, and many factories are running under-capacity even after accepting the business at the cost price. For the first time growth in our RMG export has fallen mainly on the compliance ground. So, to ensure compliance there is no way to enforce an effective SCM.

Faced with ever increasing scrutiny from multiple stakeholders - ranging from customers, non-government organizations (NGOs) and the media, to investors and legislators - the global clothing industry is under growing pressure to improve employee safety and building standards, both of which are important components of a sustainable SCM strategy. A cross-industry analysis of companies responses to the Corporate Sustainability Assessment (CSA) suggests that the global clothing sector already has a basic understanding of its supply chain risk exposures, and is even ahead of some industries, such as furnishing. Yet, it still has a long way to go towards developing a better SCM framework. Out of a possible maximum score of 100, companies in the clothing and apparel sector received an average SCM score of 44, with the top company scoring 92. Figure: Supply chain management performance by industry

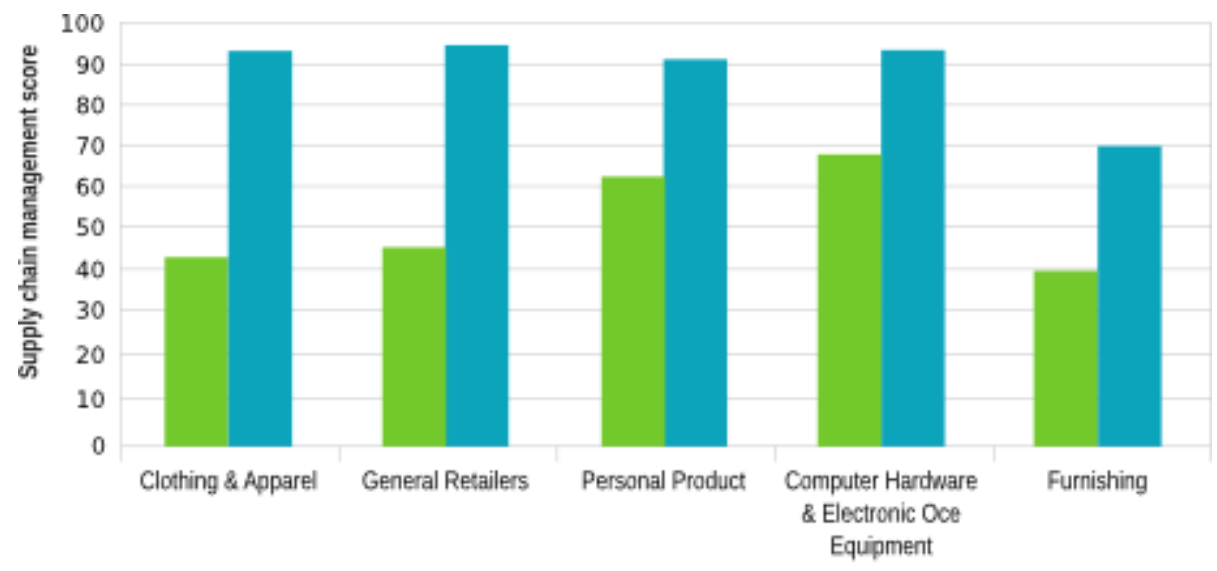

= Average Supply Chain Mangement Score = Top Supply Chain Management Score Source: Robeco SAM, 2013

Although Bangladesh has production capabilities in manufacture of thread and fabric, the country has to import almost all raw materials, primarily cotton and other manmade fiber e.g. polyester, viscose and staple fiber. The 


\section{International Journal of Science and Research (IJSR) \\ ISSN (Online): 2319-7064 \\ Index Copernicus Value (2013): 6.14 | Impact Factor (2015): 6.391}

country spends substantial foreign exchange every year to import raw materials and accessories to feed the RMG sector. Bangladesh has been facing enormous challenges to sourcing cotton to feed its twenty billion-dollar apparel industry for the last couple of years. For a country considered a rising textile power, the challenges have been the painful reminders of the intractable problems plaguing Bangladesh. With current apparel exports reaching US \$20 billion a year, Bangladesh needs to import about 800,000 MT of cotton every year. A study (McKinsey \& Company, 2011) suggests that the growth in apparel industry is likely to double by 2015 and nearly triple by 2020. If Bangladesh continues to expand its Apparel industry at this pace, the cotton consumption is also likely to double to $1.6 \mathrm{~m}$ MT by 2015 and triple to 2.5m MT by 2020 .

\section{Figure 1: Bangladesh Cotton Imports by Year}

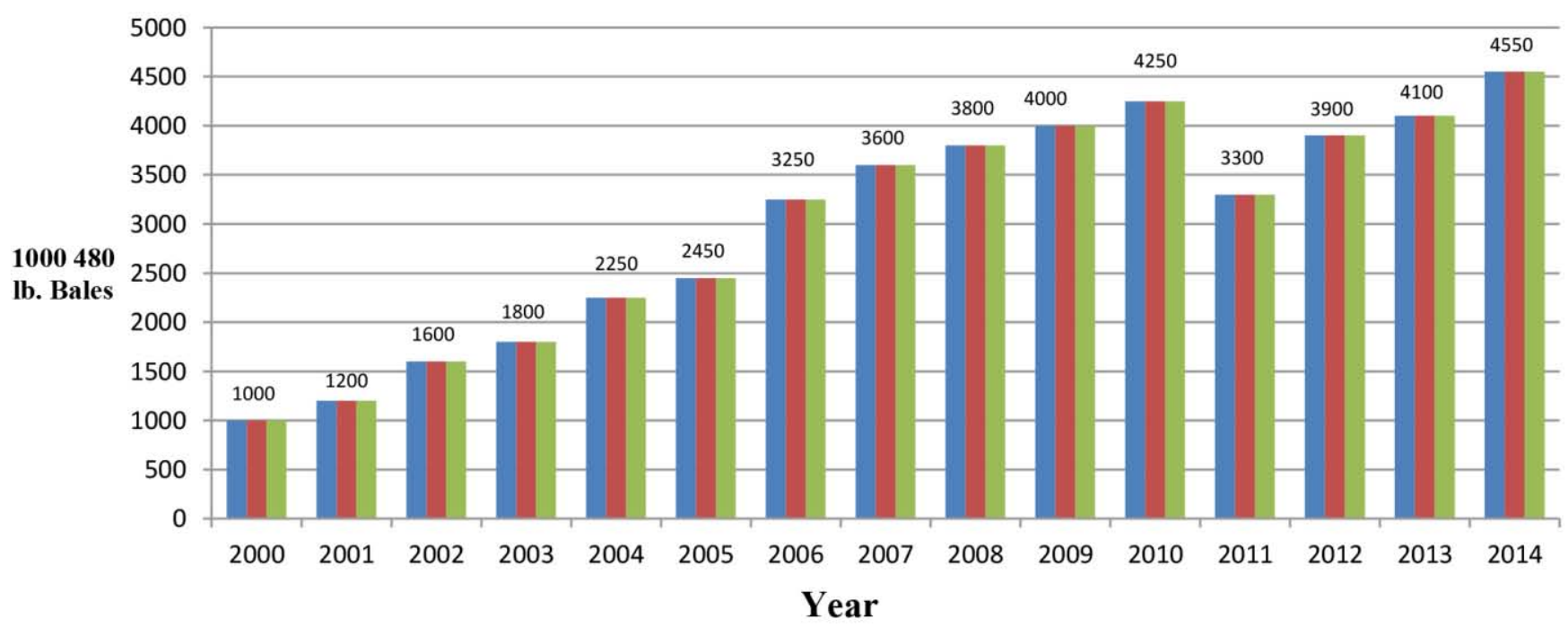

Source: Bangladesh Garment Manufacturers and Exporters Association, 2015

At the macro level the SCM system involves parties of different companies in different countries like suppliers, manufacturers and brands. In the global or macro-level links, relationship and commitment of different suppliers, services of banks, ports, customs along with transportation and documentation are interconnected. It is a difficult job to ensure an effective coordination among all the parties. In the global supply chain, crossing borders nearby supply with a multiplicity of general obstructions to intercontinental business: tariffs, nontariff obstructions, switch over rates and differences in product necessities, consumer savors and business observes. Borders also present some impediments in transportation services, which are very common for RMG sector in Bangladesh. Among the factors, beyond the factory control, are i) delayed and wrong supply of materials, ii) delayed approval, iii) style changes after confirmation or even after the start of production, iv) fabrics failing to the test requirement, v) pilferage of goods or finding them missing during transportation or at ports, especially at airports.

Due to multiplicity of the stakeholders or middlemen, it takes a lengthy process for any decision. Pending approval kills the lead time. In the whole supply chain, Bangladesh does the manufacturing job but does not manufacture basic raw materials. Our competitors like China and India have their own sources of materials. Countries like Vietnam and Cambodia need only one week to receive the materials from Shanghai. So, the lead time is another important issue in the RMG business. All of our competitors have an advantage in the lead time. In this regard the Bangladesh RMG industry has improved little; for example, the average lead time is 90 120 days for woven garment firms and 60-80 days for knit garment firms. In China, the average lead time is 40-60 days and 50-60 days for woven and knit products respectively; in India, it is 50-70 days and 60-70 days for the same products respectively. They are in a better position in the area of supply chain and compliance. Our main competitiveness is the low wage. Only wage alone cannot guarantee business growth and sustainability.

The RMG business involves a buyer-dominated supply system where garment makers have a very limited role. Unfortunately, even with a limited role in the supply chain, a factory has to face tremendous pressure to meet the lead time. In this particular business, suppliers are not static and a large number of suppliers are involved in the process of making a single shirt of a particular style. For the same buyer it is not necessary that the suppliers' list and items will be the same. The number of suppliers varies depending on style specifications. There are almost 20 items required for a single shirt. A factory dealing with 15 buyers has to handle at least 100 suppliers. Most of the factories run their operation in the traditional system i.e. not having any modern information system.

\section{Conclusion and Recommendations}

A chain is as strong as all of its rings are. Similarly, a chain is as weak as one of its rings is, i.e. one single ring is more than enough to make the whole chain dysfunctional. The RMG sector in our country has so far been witnessing very clear price competitiveness. The minimum wage in our country is still the lowest among our competitors. But our lead time is under pressure. Cheap labor does not help, if the workers are not efficient. The supply of a small quantity

\section{Volume 5 Issue 4, April 2016}




\section{International Journal of Science and Research (IJSR) \\ ISSN (Online): 2319-7064 \\ Index Copernicus Value (2013): 6.14 | Impact Factor (2015): 6.391}

with many styles within a short time is not possible without a functional supply chain system. Reducing the dependence for materials on other countries and elimination of middle men are vital to make the chain strong. Without proper management of the supply chain, only wage competitiveness cannot ensure sustainable business. So, for the sake of the sector, we have no alternative but to make the SCM effective.

In RMG supply chain, meeting lead-time, quality standard and buyers' specification are very important. Failure to comply with these requirements creates buyers ${ }^{\text {* }}$ dissatisfaction and cancellation of order. RMG products are sensitive to design, color and use of accessories. The manufacturers need to submit samples for buyers' approval before producing in a bulk quantity. If the size, color, design and other specifications are approved by the buyers, operation is started for bulk production. Sometimes, buyers reject some batches of products because of non-conformity of sample with bulk. It's a huge economic loss and loss of reputation of the company. Moreover, buyers set a fixed lead time and within this time the manufacturers need to procure, produce and deliver the finished products. If there is any deviation buyers are dissatisfied and may even reject the shipment. Therefore, the following are the recommendations that the decision makers and planners of RMG may consider as fruitful:

a) The SCM process in RMG sector is scattered in perspective of Bangladesh which is lagging behind in the global competition. To be more efficient in the Global apparel industry Bangladesh have to maintain standard SCM procedures.

b) Subsequent, Bangladesh requirements to get better the factory working environment and various social matters related to the RMG industry. International buyers are very scrupulous about compliance with codes of conduct (Wal-Mart is clearly ahead to SCM generation for an example).

c) Thirdly, issues associated to product and market diversification as well as advancement products desires to be addressed with extraordinary heed which is ensuring by SCM in a scattered manner.

d) Direct marketing and elimination of middle men can help establish an effective supply chain system. It is very difficult to make a combined and coordinated system among the interest groups involved at present. Miscommunication and misinformation at any point hamper the whole process.

e) The impact of political instability and workers' unrest destabilizing the SCM are another concern. Adaptation with changing technologies, undisrupted utility supplies, minimizing corruption, and elimination of bureaucratic tangles in customs, port management and other concerned government agencies can play a vital role in overcoming the challenges. Without combined efforts and firm commitment from all concerned, a performance-based supply chain system is not possible.

f) The textile industry is lacking the correct supply chain management know-how as the country has an acute shortage of people who understand the complex nature of supply chain management.

g) The RMG manufacturers need to start working together with all the supply chain partners, as the landscape of low cost sourcing countries is about to change. Buyers in the future would be more interested in total cost of ownership (TCO) rather than just the unit price.

h) To cut the lead time the sector needs to improve the SCM system. A buyer wants everything ready and instantly. Instead of the traditional system, now online costing and orders are now common. In the traditional system it required 120 days in case of solid fabrics and 150 days for yarn dyed. Now a factory is having 60-75 days and 90-120 days respectively. In the case of composite knit garment, a factory keeps the fabrics ready in the grey condition. After having the style details they go for dyeing and thus they can manage to keep the lead time limited to $30-45$ days for repeat orders. For any fresh order a buyer does not allow even 60-75 days, though earlier it took 90-120 days.

i) Business firms should align their supply chain strategies with all the business processes and their competitive strategies, to augment the supply chain efficiency.

j) Furthermore, the government of Bangladesh requires strengthening its prop up. The enlargement and modifying of the port's supply chain management and other physical infrastructure, the smooth supply of utilities, a corruption-free business surroundings and political stability are some precedence concerns for the government to regard as in its efforts to attract international buyers and backers.

\section{References}

[1] Tanvir, S., \& Muqaddim, N. (2013). Supply Chain Management Offering the New Paradigm for Bangladesh Garment Industry, Journal of Economics and Sustainable Development, 4, (20), page no. ISSN: 2222-1700 (Paper) ISSN: 2222-2855.

[2] Shahriar, M., F., Pathik, B., B., \& Habib, M., M., (2014). A Research Framework of Supply Chain Management in Ready Made Garments Industry of Bangladesh. International Journal of Business and Economics Research. 3, (6), 38-44. doi:10.11648/j.ijber.s.2014030601.16.

[3] Asgari, B., \& Hoque, M., A., (2014). A system dynamics approach to supply chain performance analysis of the ready-made-garment industry in Bangladesh. Ritsumeikan Journal of Asia Pacific Studies, 32, page no.

[4] Islam, M., S., (2012). Supply Chain Management on Apparel Order Process: A Case Study in Bangladesh Garment Industry. Asian Journal of Business and Management Sciences, 2(8), 62-72.

[5] Hossan, C., G., Sarker, M., A., R., \& Afroze R. (2012). Recent Unrest in the RMG Sector of Bangladesh: Is this an Outcome of Poor Labour Practices? International Journal of Business \& Management, 7, 206-218.

[6] Nuruzzaman, A. H. \& Azad, R., (2010). Is Bangladeshi RMG Sector Fit in the Global Apparel Business? Analyses the Supply Chain Management. The South East Asian Journal of Management, 4(1),

[7] Chopra,S., Meindl, P., \& D.V. Kalra, D.V. (2003). Supply Chain Management-Strategy, Planning and Operation, Pearson, India, 4th Edition, pp-7-8. ISBN: 978-81-317-3071-3

\section{Volume 5 Issue 4, April 2016




\section{International Journal of Science and Research (IJSR) \\ ISSN (Online): 2319-7064 \\ Index Copernicus Value (2013): 6.14 | Impact Factor (2015): 6.391}

[8] Nuruzzaman, A.H. (2009). Lead time management in the garment sector of Bangladesh: An avenue for survival and growth. European Journal of Scientific Research, 33, 617

[9] N. Md., "Developing Export of RMG products in Bangladesh: Analyzing the Lead time", Management Trends, Vol.4, No.1, P- 1.

[10] M.S. Islam., Supply Chain Management on Apparel Order Process: A Case Study in Bangladesh Garment Industry", Asian Journal of Business and Management Sciences, Vol. 2, No. 8, pp. 62-72, 2012.

[11] World Bank. (2005). End of MFA Quotas: Key Issues and Strategic Options for Bangladesh Readymade Garment Industry. Bangladesh Development Series Paper No. 2, PREM Unit. Washington D.C.

[12] Mohammad Ali and Dr. Md Mamun Habib; Supply Chain Management of Textile Industry: A Case Study on Bangladesh; International Journal of Supply Chain Management; Vol. 1, No. 2, September 2012; ISSN: 2050-7399 (Online)

[13] Leonie Barrie, The daily star, Bangladesh: The catalyst for change in the supply chain. Access on January 20, 2015

[14] Basher, M.A. (2010). Compliance in the RMG sector: What has been done so far, and what more needs to be done? Dhaka. Bangladesh.

[15] Duangpun Kritchanchai, and Thananya Wasusri, Implementing Supply Chain Management in Thailand Textile Industry, International Journal of Information Systems for Logistics and Management, Vol. 2, No. 2, (2007) 107-116.

[16] Mohammad Ali, Dr. Md Mamun Habib, The material requirements planning system for readymadegarments and inventory control, Journal of Applied Management and Investments, Volume 1, Number 2, 2012.

[17] Habib, Md. Mamun, Supply Chain Management (SCM): Theory and Evolution" Dr. Md. Mamun Habib (Editor), Supply Chain Management - Applications and Simulations", InTech Open Access, Croatia, September 2011, ISBN 978-953-307-250-0

\section{Author Profile}

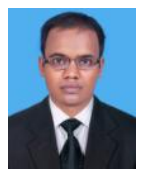

Md. Uzzal Hossain currently working as a Lecturer in the Department of Management Studies at Bangabandhu Shiekh Mujibur Rahman Science and Technology University (BSMRSTU) and accomplishing the responsibility as an Assistant Provost at Bangamata Sheikh Fojilatunnessa Mujib Hall. Before joining to this university he worked at Dhaka International University as a Lecturer of faculty of Business Administration. He has taught Introduction to Business, Human Resource Management, Principles of Management, Organizational Behavior, Entrepreneurship Development, Training and Development, Management of Change, Manpower Planning etc. courses at BBA and MBA Program. In her academic career, she has achieved BBA (Management) and MBA (Human Resource Management) degrees from University of Chittagong. His area of interests are Human Resource Management and Supply Chain Management.

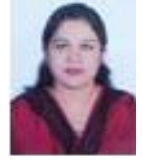

Ishita Roy is currently working as an Assistant Professor in the Department of Management Studies at Bangabandhu Shiekh Mujibur Rahman Science and Technology University (BSMRSTU) and accomplishing the responsibility as an Assistant Provost at Bangamata Sheikh Fojilatunnessa Mujib Hall. Ishita Roy has spent 10 years at the University of Development Alternative (UODA) as a faculty of Business Administration and Coordinator of BBA Program. She has taught Introduction to Business, Human Resource Management, Principles of Management, Organizational Behavior, Entrepreneurship Development, Training and Development, Management of Change, Manpower Planning etc. courses at BBA and MBA Program. In her academic career, she has achieved BBA (Management) and MBA (Human Resource Management) degrees from Dhaka University. She has written a book Principles of Finance' and an article on Perceptions and Challenges on Tax Payment Behavior: Case Study in Bangladesh'. Her area of interest is Human Resource Management. 